\title{
ACCOUNTING AND INFORMATION SUPPORT FOR THE STRATEGIC DEVELOPMENT OF SMALL BUSINESSES: TAX ASPECTS
}

\author{
Lyshchenko O.G., Myshakova V.O. \\ National University "Zaporizhzhia Polytechnic" \\ Ukraine, 69063, Zaporizhzhia, st. Zhukovsky, 64M \\ lena.lyshchenko@gmail.com, vladlena.mishakova@ukr.net \\ ORCID 0000-0001-9211-9567
}

Key words:

accounting and information support, small business entity, taxes, tax strategy, tax policy, tax optimization, calculation of tax payments.
The article considers the essence and role of accounting and information support of strategic development of small business in the context of taxation. The essence of the concepts of "accounting and information support" and "accounting information" is characterized. Theoretical bases of formation of tax strategy of the subject of small enterprise were investigated. The concept of basic economic category of research "tax strategy" is highlighted. Attention was paid to the uncertainty at the legislative level of the term "tax policy" and the definition of the concept based on "accounting policy" was proposed. Processes of formation of tax strategy were characterized, namely the importance of stages of creation of tax strategy at a small enterprise were defined and analyzed. Obligatory observance of requirements of the Tax code of Ukraine was noted. The negative consequences of the absence of a systematic document fixed in the legislation that would regulate the issues of accounting and taxation of small business are detected. The article defines the essence and role in the creation of tax policy at an enterprise. Recommendations are given on the methodology of creating an order of tax policy at a small enterprise in accordance with the norms of the Tax code of Ukraine. It was recommended to work out the methodology of tax accounting, including creation of register forms according to the needs of the business entity and also the procedure of reflection of analytical data on the accounts and data of primary documents in order to generalize the data of taxes, fees and payments. The conditions for improving the management of tax processes in an enterprise by creating a tax strategy, development of tax policy, the introduction of the process of budgeting of tax payments and the introduction of tax planning system by selecting the optimal conditions of taxation were determined. It is offered to create the generalized standard of accounting at the state level at the subjects of small enterprise.

\section{ОБЛІКОВО-ІНФОРМАЦІЙНЕ ЗАБЕЗПЕЧЕННЯ СТРАТЕГІЧНОГО РОЗВИТКУ СУБ'ЄКТА МАЛОГО ПДПРИЄМНИЦТВА: ПОДАТКОВІ АСПЕКТИ}

\author{
Лищенко О.Г., Мишакова В.О. \\ Національний університет «Запорізька політехніка» \\ Україна, 69063, м. Запоріжжя, вул. Жуковського, 64м. Запоріжжя \\ vladlena.mishakova@ukr.net
}

\begin{abstract}
Ключові слова:
обліково-інформаційне забезпечення, суб'єкт малого господарювання, податки, податкова стратегія, податкова політика, оптимізація податків, розрахунок податкових платежів.
\end{abstract}

У статті розглянуто сутність та роль обліково-інформаційного забезпечення стратегічного розвитку суб'єкта малого підприємництва в розрізі оподаткування. Надано характеристику сутності понять «обліково-інформаційне забезпечення» та «облікова інформація». Досліджено теоретичні основи формування податкової стратегії суб'єкта малого господарювання. Висвітлено поняття базової економічних категорії дослідження «податкова стратегія». Акцентовано увагу на невизначеність на законодавчому рівні терміну «податкова політика» та запропоновано визначення поняття на основі «облікової політики». Надано характеристику процесу формування податкової стратегії, а саме визначено та проаналізовано значимість етапів створення податкової стратегії на малому підприємстві. Наголошено на обов'язковість дотримання вимог Податкового кодексу України. 3'ясовано негативні наслідки відсутності за систематизованого документа закріпленого на законодавчому рівні, який регулював би питання ведення обліку та оподаткування суб'єктів малого господарювання. Визначено 
сутність та роль створення податкової політики на підприємстві. Надано рекомендації щодо методології створення Наказу про податкову політику на малому підприємстві відповідно до норм Податкового кодексу України. Для узагальнення даних обліку податків, зборів та платежів рекомендовано розробити методологію ведення податкового обліку, що включає створення форм регістрів відповідно до потреб суб'єкта господарської діяльності, а також порядок відображення в них аналітичних даних по рахунках та даних первинних документів. Визначено умови покращення управління податковими процесами на підприємстві шляхом створення податкової стратегії, розробки податкової політики, впровадження процесу бюджетування податкових платежів та введення системи податкового планування шляхом вибору оптимальних умов оподаткування. На державному рівні запропоновано створити узагальнений стандарт ведення обліку на суб’єктах малого господарювання.

\section{Statement of the problem}

Carrying out economic activities in the modern world is a business under the close supervision of the state, so businesses face the task of creating a system of accounting and information support of enterprise activities to successfully protect their interests in the legislation. To comply with tax security according to the accounting and information support, business entities need to follow the tax strategy developed in accordance with the economic and legal status, the impact of domestic and foreign market environment.

\section{Analysis of recent research and publications}

Issues of improvement of accounting and analytical support for the purposes of taxation of enterprises are studied in their studies such domestic scientists as: T.M. Bezrodnaya [2], T.S. Gresko [3], A.A. Gluschenko [4], A.A. Lagovskaya [5], S.M. Laichuk [6] and others. At the same time, issues related to the implementation of the tasks of accounting and analytical support in terms of the formation of tax strategy, especially by small businesses, as the system of tax relations requires the creation of a single base to control the accrual and payment of taxes in the enterprise are not sufficiently considered.

\section{Objectives of the article}

The aim of the study is to investigate the accounting and information support for the strategic development of the subject of small business as a basis for the formation of an effective tax strategy in the enterprise.

\section{The main material of the research}

The main problem of small business entities remains the burdensome tax system. Despite certain positive changes that took place in Ukraine because of actions to create state support for small business, the nature of taxation has changed insignificantly. To compete successfully in the competitive environment, an enterprise must optimize all available resources, including tax payments. To solve this problem, enterprise develops tax strategy according to specific objectives of enterprise based on accounting and information system.

Accounting and information support is a basic element at all stages of managerial decision-making, expressed in the identification and provision of various quantitative and qualitative indicators of information about the internal and external environment of the enterprise in accordance with the needs of the subject of management.

Information support of the decision-making process covers the receipt, movement, processing, storage, and transfer of an array of information within the framework of certain managerial goals and objectives, the study of management problems, the consideration of options for their solutions, the adoption and delivery of managerial decisions to performers, control of the execution of management decisions [5, 19].

The basis of the system of accounting and information support is accounting information.

Accounting information is information about the functioning of the subject of the economy, recorded in the media of accounting information $[2,1]$. Accounting information is accurate compared with other types of information because it is fully confirmed by primary documents, accounting calculations, and the like.

With the help of a well-functioning system of accounting and information support, an enterprise can effectively manage costs, especially in terms of taxation. The most effective measure for managing the tax payments of an enterprise is the implementation of a tax strategy created in accordance with the peculiarities of the enterprise's business.

To disclose the definition of "tax strategy" it is necessary to reveal the essence of economic category "strategy".

In research strategy is understood as pre-planned reaction of the enterprise on change of external environment, for protection of own interests.

In his research A.V. Balashov [1] gives the definition of "tax strategy" as a generalized model of behavior within the limits of the current tax legislation, providing increase of efficiency of activity of the enterprise by means of optimization of tax payments. We agree with this definition, but we emphasize that the tax strategy is also a set of rules that guide the enterprises in making management decisions.

The main objective of introducing a tax strategy of an enterprise is tax optimization.

Tax optimization involves minimizing tax payments and avoiding penalties from the controlling authorities. 
These tasks are achieved due to the correctness of accrual and timely payment of taxes in accordance with the norms of the Tax Code [9], which in turn is inextricably linked to tax planning in an enterprise.

Since the main goal of starting an entrepreneurial activity is to make a profit, creating a tax strategy in an enterprise determines an additional means of achieving this goal through optimization of tax payments.

The main factors that should be considered first in the development of tax strategy include normativelegislative base on taxation, state of industry and position in the enterprise market, degree of dependence on external environment, financial resources.

A small business entity faces the problem of determining the necessary data at the legislative level on conducting business activities, as in Ukraine there is not a single systematized document regulating accounting and taxation. In the world practice the International Financial Reporting Standard for Small and Medium-sized Enterprises (IFRS for SMEs), which gives explanations of the main aspects of doing business by small business entities [7], has received general consumption.

Drawing up a tax strategy of a small business entity begins with an estimation of advantages and drawbacks of different systems of taxation (table 1) and further budgeting of expenses at least for the first quarter. According to the Tax Code of Ukraine [9] enterprises can choose general or simplified system of taxation, accounting, and reporting.

Table 1 - Advantages and disadvantages of the simplified taxation system for the payers of the third group of the simplified taxation system

\begin{tabular}{|l|l|}
\hline \multicolumn{1}{|c|}{ Benefits } & \multicolumn{1}{c|}{ Flaws } \\
\hline $\begin{array}{l}\text { 1. Reduction (as compared } \\
\text { to the general system) } \\
\text { in the number of taxes. }\end{array}$ & 1. Limited volume of income. \\
\hline $\begin{array}{l}\text { 2. Due to the reduction } \\
\text { of taxes the number of } \\
\text { reporting forms to the } \\
\text { controlling bodies decreases, } \\
\text { and therefore the possibility } \\
\text { of mistakes and penalties } \\
\text { is reduced. }\end{array}$ & $\begin{array}{l}\text { 2. Impossibility of barter } \\
\text { transactions, netting, } \\
\text { application of bills of exchange } \\
\text { means. }\end{array}$ \\
\hline $\begin{array}{l}\text { 3. Possibility to } \\
\text { independently choose } \\
\text { the status of VAT payer } \\
\text { regardless of the volume of } \\
\text { taxable operations }\end{array}$ & $\begin{array}{l}\text { 3. When importing goods } \\
\text { into the customs territory of } \\
\text { shall pay taxes on general } \\
\text { grounds. }\end{array}$ \\
\hline & $\begin{array}{l}\text { 4. Lack of transitional } \\
\text { provisions in case of changes } \\
\text { in taxation system. }\end{array}$ \\
\hline
\end{tabular}

Source: compiled by the author based on [9]

According to the calculated budget, if expenses are expected to grow in the next tax period (entering a new market, increasing the number of orders, buying new equipment, expanding the assortment by building a new production line), then the optimal choice for the enterprise is the general system of taxation and payment of profit tax. If cost reduction is predicted (change in technology, reduction of production volume, reduction of assortment) - it is necessary to switch to the simplified system of taxation.

The main stage in the formation of the tax strategy of the enterprise is the creation of tax policy.

The concept of "tax policy" is not defined at the legislative level in Ukraine, but the term "accounting policy" is defined.

According to the Law of Ukraine "About accounting and financial reporting" [8] accounting policy is a set of principles, methods and procedures used by the enterprise for accounting, preparation, and presentation of financial statements. Based on this definition, we can say that the tax policy is a set of principles, methods and procedures used by the enterprise to conduct tax accounting, preparation, and presentation of tax reports.

The main difference between these concepts is that the accounting policy fixes only those principles and methods of accounting and evaluation, which provide the choice of alternatives for the enterprise or for which there is uncertainty and are used by the enterprise for financial reporting, while the tax policy discloses principles and methods and the necessary information about the enterprise for tax reporting. Thus, the tax policy of the enterprise should indicate the guidelines of the enterprise in the direction of reducing tax liabilities, depicts the methods used, goals, describes the desired image of the enterprise, the chosen model of behavior in relation to the performance of tax liabilities and the like.

The accounting policy for taxation purposes should provide for methodology of tax accounting, including developed forms of registers for accounting of taxes, fees and payments, as well as the order of reflection of analytical data on accounts and data of primary documents in them.

Registers can be represented in the form of tables, tax calculations or cards, which include information on the objects of taxation, the primary organizational and administrative and other documents confirming the correctness and legality of the business operations. Such registers serve as auxiliary documents in the preparation of tax reports for the relevant period, sent to the supervisory authority [4].

Also, to simplify the process of determining the tax base, it is necessary to develop tax information on each object of taxation, which contains information on the tax base and tax rates. Integral appendices to the tax information can be primary documents for acquisition, inventory, preservation, liquidation, etc.

We believe that tax policy should be executed at an enterprise in the form of a dispositive document (order, resolution, determination, order, instruction). In practice, the most common type of document is an order.

The order is the main administrative document, with the help of which main and operational tasks are solved on the rights of sole authority. It is issued by the head of the company and is obligatory for execution.

The order "About tax policy" is an important element of introduction of tax accounting, as it is a legal proof 
of legitimacy of introduction of business operations connected with taxation.

For taxation purposes the order "On tax policy" should be applied from the first day of the quarter following the current quarter and could be changed once in a quarter by a relevant order of the head. The reason for changing the tax policy of the company can be significant changes in the tax law, the tax system, the legal or organizational and economic status of the company.

At the final stage, the enterprise analyzes the effectiveness of the tax policy introduction. For this purpose, the level of tax burden (tax pressure, tax burden) of the reporting tax period is compared with the previous period.

Making the final decision on further adherence to tax strategy, its improvement or change determines the enterprise based on preliminary study of the effectiveness of tax policy of the enterprise.

So, to improve the management of tax processes by involving accounting and analytical support in the enterprise it is necessary:

- creation of a tax strategy in the enterprise for tax optimization.
- development of a tax policy of an enterprise in the form of an order "On Tax Policy" for a unified approach to accounting for taxes, fees, and payments.

- ensuring the calculation of current tax payments by determining the amounts of tax liabilities and the schedule for their repayment.

- introduction of the tax payment budgeting process aimed at determining the amount of future tax liabilities.

- introduction of a tax planning system by selecting the optimal taxation conditions.

Also, at the national level it is necessary to develop a generalized standard of accounting in small businesses on the example of the International Financial Reporting Standard for small and medium-sized enterprises.

\section{Conclusions}

Accounting and information support serves to ensure effective management at the enterprise. When carrying out financial and economic activities qualitative accounting and information system provides real reduction of costs at the enterprise by means of tax optimization. The most effective criteria of tax optimization are minimum tax payments of enterprise during tax period, minimum tax burden, ensuring uniformity of tax liabilities formation according to available resources.

\section{References}

1. Balashova, O.V. (2004), "Tax mechanism for stimulating investment activity of industrial enterprises", Ph.D Thesis, Economic security. Priazovsky state Technical University, Mariupol, Ukraine [in Ukrainian].

2. Bezrodna T.M. (2008) "Accounting and analytical support of enterprise management: the definition of the essence", Bulletin of the East Ukrainian National University. V. Dahl, vol. 10, pp. 58-62 [in Ukrainian].

3. Greskiv, T.S. (2008) "Formation and improvement of the accounting tax policy of the enterprise", Derzhava $i$ rehiony, vol. 6, pp. 76-79 [in Ukrainian].

4. Glushchenko, O.O. (2011) "The company's tax strategy as an effective measure of economic security", Problemy material'noi kul'tury, vol. 215, pp. 41-44 [in Ukrainian].

5. Lahovs'ka, O.A. Lehenchuk, S.F. Kuz', V.I. and Kucher, S.V. (2017), Bukhhalters'kyj oblik v upravlinni pidpryiemstvom [Accounting in enterprise management], Zhytomyrs'kyj derzhavnyj tekhnolohichnyj universytet, Zhytomyr Ukraine [in Ukrainian].

6. Laychuk, S.M. (2006) “Tax policy of small business entities”, Visnyk Zhytomyrs 'koho derzhavnoho tekhnolohichnoho universytetu, vol. 4, pp. 485-527 [in Ukrainian].

7. International Financial Reporting Standard for Small and Medium-sized Entities (IFRS for SMEs), available at: https://zakon.rada.gov.ua/laws/show/929_063 [in Ukrainian].

8. The Verkhovna Rada of Ukraine (1999), The Law of Ukraine "On accounting and financial reporting in Ukraine", Vidomosti Verkhovnoi Rady Ukrainy, vol. 40, p. 365 [in Ukrainian].

9. The Verkhovna Rada of Ukraine (2011), The Law of Ukraine "Tax Code of Ukraine", Vidomosti Verkhovnoi Rady Ukrainy, vol. 13-14, vol. 15-16, vol. 17., p. 112 [in Ukrainian]. 